УДК 331.452

О. Є. Кружилко, Я. Б. Сторож, І. М. Ткалич, О. І. Полукаров

\title{
ПШДВИЩЕННЯ ЕФЕКТИВНОСТІ УПРАВЛІННЯ ОХОРОНОЮ ПРАЦІ НА ОСНОВІ ВИЯВЛЕННЯ НЕБЕЗПЕК ТА ОЦІНКИ РИЗИКІВ ВИРОБНИЧОГО ТРАВМАТИЗМУ
}

Анотація: У статті наведено рекомендації з виявлення небезпек на робочому місці на основі аналізу міжнародного досвіду для подальшої оцінки ризиків. Проведено експериментальне дослідження, яке полягало у виявленні небезпек, що спричинили смертельні нещасні випадки у 2016-му році (на прикладі підприємств будівництва та промисловості будматеріалів).

Ключові слова: фактори небезпеки, оцінювання ризиків, анкета небезпек.

\section{Вступ}

Підвищення рівня захисту працівників від професійних ризиків в процесі їх трудової діяльності є одним з головних напрямків діяльності всіх фахівців з охорони праці, а скорочення виробничих травм і професійних захворювань залишається найважливішою завданням усіх рівнів управління охороною праці з будьякої точки зору - гуманітарної, соціальної та економічної, особистої, корпоративної та громадської.

\section{Постановка задачі}

Проведений аналіз свідчить, що для підвищення ефективності управління охороною праці на підприємствах пропонуються переважно підходи, що базуються на реактивних заходах, механізм превентивних дій не надто розвинений або не реалізується через брак фінансово-адміністративних важелів. Результативність управління оцінюється за показниками виробничого травматизму, хоча ці показники фіксують наслідки процесів управління, коли час для превентивних заходів упущений. Забезпечення об’єктивних кількісних оцінок ризику травмування на виробництві та обгрунтування на їх основі заходів 3 профілактики набула останнім часом особливої актуальності. При цьому необхідно виконати формалізований опис процесу виникнення виробничої травми, виявлення основних закономірностей причинно-наслідкових зв'язків в процесі травмування, а також кількісного оцінювання впливу на рівень виробничого травматизму різноманітних причин і визначення критеріїв та методів обгрунтування рішень 3 профілактики травматизму. Оцінка виробничих ризиків полягає у всеосяжному і систематичному виявленні небезпек і визначенні величини ризиків. Загальною метою оцінки ризиків є підвищення рівня безпеки праці.

(c) О. Є. Кружилко, Я. Б. Сторож, І. М. Ткалич, О. І. Полукаров 
Оцінка ризиків є найбільш ефективним превентивним заходом. При оцінці ризиків враховуються не тільки несприятливі події і нещасні випадки, що сталися раніше, але й небезпеки, які поки що не викликали несприятливих наслідків. Їх виявлення до того, як вони завдадуть шкоди здоров'ю, дозволяє забезпечити усунення цих небезпек або зниження їх впливу до безпечного рівня.

Оцінка ризиків є безперервним і систематичним процесом. Вона проводиться поетапно, з урахуванням раніше виявлених небезпек. Докладні рекомендації по методиці проведення оцінки ризиків, а також рекомендації щодо подальших заходів в залежності від результатів цих оцінок відображені в документах Міжнародної організації праці $[1,2]$. Ці рекомендації носять загальний характер і універсальні для всіх організацій і підприємств, проте для кожної галузі необхідно здійснювати облік небезпек, які характерні для іï виробничих умов і технологічного забезпечення.

\section{Виявлення небезпек}

Виявлення небезпек є початковим і найважливішим етапом оцінки ризиків. При цьому необхідно знайти відповіді на наступні питання:

- які фактори небезпеки присутні при виконанні роботи?

- що є причинами небезпеки?

- де проявляється небезпека?

- $\quad$ хто схильний до небезпеки?

- в яких ситуаціях працівники можуть наразитися на небезпеку?

\section{Облік факторів небезпеки}

Виявлення небезпек передбачає визначення та облік небезпеки для здоров'я працівників беручи до уваги характер трудової діяльності, виробничого приміщення, інших робочих зон і умов праці. Необхідно враховувати раніше виявлені небезпеки, а також такі фактори небезпеки, які можуть завдати шкоди в силу особистих даних працівників і факторів трудової діяльності. Фактори небезпеки можна легко розпізнати роблячи контрольний обхід робочого місця, спостерігаючи за ходом роботи і опитуючи працівників. Під час запису факторів небезпеки слід фіксувати також всі уточнення, що стосуються цього питання, коментарі та питання.

Фактори небезпеки, що виникають в роботі (таблиця 1), необхідно виявляти і оцінювати на всіх робочих місцях, в тому числі, в громадському і приватному секторах, незалежно від розміру робочого місця і сфери діяльності. Способи та методи виявлення та оцінки можна вибирати відповідно до особливостей робочого місця, при цьому повинні враховуватися всі види робіт і всі фактори небезпеки. За допомогою безперервного і систематичного контролю можна забезпечити безпеку праці та виявити раніше приховані небезпеки та недоліки в іiі організації. 


\section{Таблиияя 1}

\begin{tabular}{|c|c|}
\hline $\begin{array}{c}\text { Фізичні } \\
\text { фактори } \\
\text { небезпеки }\end{array}$ & $\begin{array}{l}\text { Постійний шум; імпульсний шум; температура повітря на робочому } \\
\text { місці; загальний обмін повітря та місцева витяжка; протяг; холодні і гаря- } \\
\text { чі предмети, праця на відкритому повітрі, загальне освітлення, місцеве } \\
\text { освітлення на робочому місці, безпечне і сигнальне освітлення шляхів } \\
\text { пересування, зовнішнє освітлення, вібрація, іонізуюча радіація, ультрафі- } \\
\text { олетове випромінювання, лазерне випромінювання, інфрачервоне випро- } \\
\text { мінювання, електромагнітні поля }\end{array}$ \\
\hline $\begin{array}{l}\text { Нещасні } \\
\text { випадки }\end{array}$ & $\begin{array}{l}\text { Небезпека послизнутися; небезпека спіткнутися; падіння з висоти, } \\
\text { включаючи підйоми та спуски; затиснення між предметами, небезпека } \\
\text { залишитися в замкненому приміщенні; електричні пристрої і статичний } \\
\text { струм; перевезення вантажу та інший рух; недостатня кількість або відсу- } \\
\text { тність кисню; небезпека попадання в воду; небезпека від падіння предме- } \\
\text { тів; відсутність засобів індивідуального та колективного захисту; небез- } \\
\text { печна праця та ризик; надзвичайні ситуації; вживання алкоголю та } \\
\text { наркотиків; недоліки аварійної сигналізації і засобів порятунку; недоліки } \\
\text { в системі надання першої медичної допомоги }\end{array}$ \\
\hline Ергономіка & $\begin{array}{l}\text { Чистота та порядок на робочому місці; шляхи руху; шляхи евакуа- } \\
\text { ції; виходи; драбини та пандуси; висота робочої поверхні; сидіння; екрани } \\
\text { та монітори; положення спини; положення рук; положення зап’ясть і па- } \\
\text { льців; положення голови та шиї; положення ніг; постійне положення си- } \\
\text { дячи або стоячи; перерви в роботі та робочий ритм; монотонність праці; } \\
\text { підйоми тягарів і перенесення вантажів; інструменти, устаткування, при- } \\
\text { строї, деталі, що обробляються; допоміжні засоби; достатня площа робо- } \\
\text { чого приміщення; можливість змінювання робочого положення }\end{array}$ \\
\hline $\begin{array}{c}\text { Хімічні } \\
\text { та біологічні } \\
\text { фактори } \\
\text { небезпеки }\end{array}$ & $\begin{array}{l}\text { Небезпечні та шкідливі хімічні речовини; речовини, які визивають } \\
\text { рак; речовини, які визивають алергію; пожежовибухонебезпечні речови- } \\
\text { ни; пил і волокна; гази; пари; аерозолі, конденсації і дими; позначення на } \\
\text { упаковках хімічних речовин; відомості про безпечне використання; спо- } \\
\text { соби використання хімічних речовин; зберігання речовин; вибраковуван-- } \\
\text { ня хімічних речовин; справність і використання засобів захисту; готов- } \\
\text { ність до використання засобів першої медичної допомоги; справність і } \\
\text { використання електроустановок; }\end{array}$ \\
\hline $\begin{array}{c}\text { Хімічні та } \\
\text { біологічні } \\
\text { фактори } \\
\text { небезпеки }\end{array}$ & $\begin{array}{l}\text { дозвіл на вогневі роботи та їх виробництво; засоби пожежога- } \\
\text { сіння і позначення на них; шляхи евакуації і їх позначення }\end{array}$ \\
\hline $\begin{array}{l}\text { Психологічне } \\
\text { навантаження }\end{array}$ & $\begin{array}{l}\text { Одноманітна праця; праця поодинці або нічна праця; тривале } \\
\text { неспання; примусовий ритм праці; напруженість відносин між лю- } \\
\text { дьми; поспіх; дуже жорсткі вимоги або цілі; відсутність перспекти- } \\
\text { ви в просуванні; робочий інструктаж та ознайомлення } 3 \text { роботою; } \\
\text { етапи роботи; опис завдань і відповідальності; робочий час; понад- } \\
\text { нормова праця і робочі зміни; ненадійність трудових відносин; не- } \\
\text { доліки в керівництві працею або організацією; нездорова робоча } \\
\text { атмосфера; недостатність інформації; загроза насиллю; неділові } \\
\text { форми звернення; відсутність соціальної підтримки }\end{array}$ \\
\hline
\end{tabular}

Необхідно враховувати небезпечні ситуації, що виникають як при звичайному ході робочого процесу, так і у виняткових і рідкісних ситуаціях. винятковими ситуаціями можна вважати, наприклад: 
- час пік і сезонні періоди;

- час відпусток;

- використання тимчасових працівників і практикантів;

- понаднормові роботи і нічні зміни;

- заплановані та незаплановані простої;

- зміни у виробничому процесі і ремонти;

- відмінності від звичайного праці, збої, дефекти і помилки;

- прибирання, ремонт та обслуговування обладнання під час роботи.

\section{Анкети з виявлення небезпек}

Початковим етапом процедури оцінки ризику є виявлення основних причин, які можуть призвести до травми або професійного захворювання, тобто факторів небезпеки, які мають фізичну, хімічну, біологічну, ергономічну або психофізіологічну природу [3, 4].

Виявлення небезпек відбувається за допомогою анкет. Анкети є швидким та простим засобом виявлення небезпек, які виникли на робочих місцях.

Відповідно до вітчизняної класифікації шкідливих і небезпечних факторів виробничого середовища [5] анкети розділені на п'ять категорій виробничих факторів, а саме фізичні, ергономічні, хімічні, біологічні, психофізіологічні та небезпеки нещасного випадку. У кожній анкеті згадано про 16-20 фактори небезпеки або небезпечних ситуацій. Фактори небезпеки розділені за допомогою підзаголовків на групи для полегшення обробки.

Фізичними факторами ризику є шум, температура, рух повітря, освітлення, радіація тощо. Фізичні фактори небезпеки є загальними факторами виробничого середовища та бувають однаковими на різних робочих місцях.

До небезпек нещасного випадку відноситься раптове і некероване джерело енергії: предмет, який рухається, некерований рух або енергія. Анкета небезпек нещасного випадку придатна для контролю таких робіт, в яких є численні етапи, механізми і пристрої, а також для праці в умовах, які змінюються. Приклад анкети виявлення небезпек нещасного випадку наведена в таблиці 2.

Під ергономікою розуміють відповідність праці, методів і засобів праці можливостям людини. В ергономіці контролюють фізичне навантаження і незручні робочі пози. Анкета по ергономіці включає питання, що стосуються робочого місця, характеру роботи і знарядь праці. Розділ про фізичні навантаження підходить для контролю робіт, що включають багато ручних операцій.

Під хімічними факторами ризику розуміють ризики заподіяння шкоди здоров'ю при використанні шкідливих речовин, сполук і порошків. За допомогою анкети хімічних факторів небезпеки можна зробити початкове картографування 3 подальшими вимірами і оцінкою хімічних небезпек. 


\section{Таблиця 2. Анкета для визначення небезпеки нещасного випадку}

\begin{tabular}{|c|c|c|c|c|}
\hline & & $\begin{array}{l}\text { Викликає } \\
\text { небезпеку } \\
\text { або шкоду }\end{array}$ & $\begin{array}{c}\text { Небезпека } \\
\text { або шкода } \\
\text { відсутні }\end{array}$ & $\underset{\text { відсутні }}{\text { Дані }}$ \\
\hline Xapa & тер праці & & & \\
\hline H 1 & Небезпека послизнутися & & & \\
\hline H 2 & Спотикання & & & \\
\hline H 3 & Підйом або падіння з висоти & & & \\
\hline H 4 & Затиснення між предметами & & & \\
\hline H 5 & $\begin{array}{l}\text { Небезпека залишитися } \\
\text { в замкненому приміщенні }\end{array}$ & & & \\
\hline H 6 & $\begin{array}{l}\text { Електричні пристрої } \\
\text { i статичний струм }\end{array}$ & & & \\
\hline H 7 & Перевезення вантажу та інший рух & & & \\
\hline H 8 & Відсутність кисню & & & \\
\hline H 9 & Небезпека попадання в воду & & & \\
\hline Пред & ети та речовини & & & \\
\hline H 10 & Падіння предметів з висоти & & & \\
\hline H 11 & Перекидання предметів & & & \\
\hline H 12 & $\begin{array}{l}\text { Удар, що викликається } \\
\text { рухомим предметом }\end{array}$ & & & \\
\hline H 13 & Затискання рухомим предметом & & & \\
\hline H 14 & Небезпека порізів & & & \\
\hline H 15 & Колоті рани & & & \\
\hline Діяль & пість людини & & & \\
\hline H 16 & Відсутність засобів безпеки & & & \\
\hline H 17 & $\begin{array}{l}\text { Незахищена та пов'язана з ризиком } \\
\text { праця }\end{array}$ & & & \\
\hline H 18 & Надзвичайні ситуації та недоліки & & & \\
\hline H 19 & Вживання алкоголю або наркотиків & & & \\
\hline Інші & ожливі фактори небезпеки & & & \\
\hline H 20 & $\begin{array}{l}\text { Недоліки аварійної сигналізації } \\
\text { і засобів порятунку }\end{array}$ & & & \\
\hline H 21 & $\begin{array}{l}\text { Недоліки в системі надання } \\
\text { першої медичної допомоги }\end{array}$ & & & \\
\hline Оцін & ризику & & & \\
\hline
\end{tabular}


Психологічне перевантаження - надмірне або недостатньо інтелектуальне навантаження. В анкеті згадані загальновідомі джерела втоми і стресу які є загальними майже для всіх робочих місць. Психологічні навантаження є частиною загального навантаження, викликаного працею, при цьому вони є істотною частиною ризику, який підлягає розрахунку.

Кожна 3 п'яти анкет є індивідуальною, таким чином, їх можна використовувати окремо. Разом ці п'ять різних тематичних анкет утворюють сукупність усього діапазону оцінки ризиків, в якій враховані всі приватні чинники виробничого середовища і трудового процесу.

Виявлених небезпек може виявитися досить багато. Вони потребують ранжирування по своїй величині. Оскільки виявлені небезпеки неможливо ліквідувати відразу, заходи щодо підвищення безпеки необхідно планувати в порядку відповідно до величини ризику. Для цього складається «профіль факторів небезпеки» або іншими словами« профіль ризиків» [4].

Профіль ризиків - це документ, в якому відображаються всі ризики, що виникають, або які можуть виникнути на робочому місці.

Профіль ризику є простим способом візуального відображення підсумків оцінки ризиків. Профілі можна зробити різними способами, наприклад, за видам ризиків відповідно до кількості небезпек, або величиною ризиків, або відносними частинами різних видів ризиків за всіма виявленими факторам небезпеки.

Рішення про значимість ризиків означає їх розмежування, при якому відокремлюються малі ризики. Ліквідація всіх ризиків не завжди можлива. Тому, в першу чергу слід зайнятися найбільш вираженими ризиками, а потім поширити заходи на інші.

Мета визначення величини ризику полягає у встановленні його ступеня i ранжуванні факторів небезпеки в порядку їх величини. Визначаючи величину ризику можна виділити з групи найбільш важливі питання або найбільші ризики з точки зору безпеки. Це дозволить згодом ефективно зосередитися на найбільш проблемних питаннях.

3 метою практичної апробації викладеного підходу до оцінювання ризиків проведено експериментальне дослідження, яке полягало у визначенні кількості факторів небезпеки, що спричинили смертельні нещасні випадки у 2016-му році (на прикладі підприємств будівництва та промисловості будматеріалів). Статистичні дані для проведення дослідження взято з баз даних інформаційної системи (IC) «Повідомлення».

Результати проведеного анкетування відповідно представлено у табл. 3. 


\section{Табличя 3}

\begin{tabular}{|l|l|l|l|}
\hline \multicolumn{1}{|c|}{ Фактори небезпеки } & \multicolumn{1}{|c|}{ Кількість } & \multicolumn{1}{|c|}{ Відсоток } & \multicolumn{1}{c|}{ Профіль } \\
\hline Характер праці & 21 & 51,22 & XXXXXXX \\
\hline Предмети та речовини & 14 & 34,15 & XXXXX \\
\hline Діяльність людини & 3 & 7,32 & $\mathrm{X}$ \\
\hline $\begin{array}{l}\text { Інші можливі фактори не- } \\
\text { безпеки }\end{array}$ & 3 & 7,32 & $\mathrm{X}$ \\
\hline Усього & 41 & 100,00 & \\
\hline
\end{tabular}

IC «Повідомлення» призначена для виконання всіх операцій з обробки даних про випадки виробничого травматизму, які підлягають спеціальному розслідуванню, а саме: смертельні та групові нещасні випадки, а також нещасні випадки 3 тяжкими наслідками. Вхідними даними для IC «Повідомлення»є акти про нещасні випадки за формою Н-1, які заповнюються згідно з Порядком розслідування та ведення обліку нещасних випадків, професійних захворювань і аварій на виробництві (затвердженого постановою Кабінету Міністрів України від 30.112011 р. № 1232). Структура бази даних IC «Повідомлення» містить поля, необхідні для проведення поглиблено аналізу та визначення ризику: дата і час настання нещасного випадку, прізвище потерпілого, стаж його роботи тощо. В IC «Повідомлення» використовуються класифікатори: вид події, що призвела до нещасного випадку, причини нещасного випадку тощо, а також загальнодержавні класифікатори КАТУУ, КФВ та інші.

Отримані результати свідчать про те, що на ризик виробничого травматизму зі смертельним наслідком на підприємствах будівництва та промисловості будматеріалів значною мірою впливають такі фактори небезпеки: характер праці, предмети та речовини. Вплив інших факторів можна вважати незначним.

\section{Висновки}

1. На підприємствах повинні бути задіяні процедури виявлення існуючих небезпек та оцінки виробничого ризику, які використовуються при плануванні та реалізації необхідних профілактичних заходів. Способи та методи виявлення та оцінки ризиків необхідно обирати відповідно до особливостей робочого місця, при цьому повинні враховуватися всі види робіт і всі фактори небезпеки.

2. Відсутність загальноприйнятих методик (методів, алгоритмів), що можуть застосовуватися для аналізу та кількісного оцінювання ризику травмування на виробництві на сьогодні нажаль не існує. Використання міжнародного досвіду на окремих підприємствах дозволяє істотно покращити стан виробничої безпеки, але подібних прикладів дуже мало.

3. На державному рівні в умовах відсутності узагальнених баз даних про умови праці та небезпеки на робочих місцях найбільш ефективним способом 
оцінки ризиків залишається дослідження причин та обставин нещасних випадків, на основі чого здійснюється обгрунтування профілактичних заходів та формування рекомендацій.

\section{Список використаних джерел}

1. Оценка рисков на рабочем месте : практическое пособие : [перевод с финского] / Мерви Муртонен; [науч. ред. : Г. З. Файнбург]; VTT-техн. исслед. центр Финляндии, М-во социал. обеспечения и здравоохранения Финляндии, Отд. охраны труда. - М. : Международная организация труда, 2011. - 63 с.

2. МОТ. Окружающие факторы на рабочем месте. Инструкция МОТ. - Женева, Бюро Международной Организации Труда, 2001 (ISBN 92-2-111628-X).

3. Парменова Д. Г. Систематизация факторов опасности для построения профиля риска судовых работ / Д. Г. Парменова // Науковий вісник Херсонської державної морської академії. - 2014. - № 1. - С. 30-35.

4. Кружилко О. Є. Алгоритм вибору методів та визначення результативності оцінки ризику / О. Є. Кружилко, О. В. Богданова // Вісник Кременчуцького національного університету імені Михайла Остроградського. Екологічна безпека. Кременчук: КрНУ, 2016. - Вип. 2 (97), част. 1. - С. 76-81.

5. ГОСТ 12.0.003-74. ССБТ. Опасные и вредные производственные факторы. Классификация. 